\title{
VISIT TO THE SCIENCE SCHOOLS, SOUTH KENSINGTON.
}

\author{
(By permission of the Science and Art Department.) \\ Saturday, March 20Th, 1886.
}

Director: Prof. Judd, F.R.S., President of the Geological Society, Professor of Geology at the Normal School of Science and Royal School of Mines.

(Report by The President.)

The visitors to the number of over one hundred met in the Entrance Hall at 2.30, and then seated themselves in the large Chemical Lecture Theatre, where Prof. Judd gave a sketch of the history and development of the Schools, and of the methods of study therein followed.

The School of Mines and of Science applied to the Arts was founded in 1851 by that enlightened and energetic geologist Sir Henry de la Beche in connection with the Geological Survey and with the Museum of Geology in Jermyn Street. A few years ago the School was reorganized with the object of the better enabling it to carry out the aims of its founder, and the classes were gradually transferred to Kensington. At the present time only the lectures relating to mining are delivered at Jermyn Street.

The course of instruction in the Schools is arranged in eight divisions-Chemistry, Physics, Mechanics, Biology, Geology, Agriculture, Mining, and Metallurgy. In each of these courses of lectures are delivered, but especial prominence is given to practical instruction, so far as is possible in or near London. The work is now so arranged that students take up one subject at a time, and concentrate their attention solely upon that. In all divisions there is a three-years' course.

The course of instruction in Geology is as follows :-During the first term of the first year students devote themselves to Chemistry, attending one lecture daily, the rest of the term being given to practical work in the laboratories ; in the second term they take up Physics. In the second year they first study Biology, and in the second term commence the study of Geology, which is continued through its various sub-divisions-Mineralogy, Petrography, \&c. -to the end of the third year.

Vol. IX., No. 8. 
Prof. Judd pointed out that there is no museum attached to the School. This he declared to be a distinct advantage, becanse stndents, instead of wandering in bewilderment through a vast collection, are required to know thoroughly a series of selected specimens, and then to proceed in detail through other small collections more advanced and of wider range. Frequent excursions are made in the neighbourhood of London, during which the students are instructed in field-geology, and are required to construct geological sections of the districts visited.

At the end of their course the ablest students are encouraged to devote themselves to some branch of original research, every aid and facility to this end being afforded them. The number of pupils in the Schools is generally between 150 and 200 , some 50 or 60 entering yearly. Prof. Huxley is the Dean of the School, in which for nearly 30 years he was the professor of Biology.

At the conclusion of this address the party walked slowly through the various laboratories and lecture-rooms-Metallurgical, Physical, and Chemical-gradually ascending to the upper stories of the lofty building, where are situated the biological and geological rooms. In one of these a large collection of apparatus employed in various parts of the geological course was laid out, including specific-gravity instruments, balances, and specific-gravity bottles, Jolly's spring balance, Nicholson's areometer, Walker's steelyard balance, Parish's balance, Attwood's balance, Mohr's displacement method, Pisani's displacement apparatus, liquids of high density used for separating the constituents of powdered rocks, scales of hardness and of fusibility, series of common rock-forming minerals, models of crystals, blow-pipe apparatus, mieroscopes, instruments used in geological field-observations, levels, compasses, clinometers, \&c.; and examples of work done by the students-drawings of crystals, of microscopical rock-preparations, geological sections, and field sketches.

Although not termed a "museum," the teaching collections of minerals, rocks, and fossils at the Science Schools are sufficiently full and complete for the most advanced student. Some time was spent in these rooms, the members examining the arrrangements with much interest. The elementary collections, which every student is required to know thoroughly, are arranged in table-cases always open to inspection; the more advanced collections being in drawers beneath. The specimens are to be handled, and may be 
put to every legitimate use by the student. When these are well mastered the student is in a position to take advantage, if desirable, of the great national collections in Cromwell Road. Over the table-cases and drawers, which contain the fossils, there are coloured vertical sections and diagrams of the geological formations and their sub-divisions, showing the variations in their development in different districts. The walls are hung with photographs, diagrams, \&c.

The lecture-room is used by the professors of both Geology and Biology. Around it, in cases or about the walls, are skeletons, preparations, casts, or reproductions in glass of the chief forms of the animal kingdom. In this room an address was delivered by Mr. G. A. J. Cole, Professor Judd's chief assistant, on "The Preparation of Microscopic Sections of Rocks and Minerals," illustrated by the apparatus employed and by drawings upon the black-board.

Mr. Cole explained the use of the lapidary's machine for the cutting of thin slices of racks, and the various processes of grinding necessary for reducing a slice-or a chipped-off flake-to a thinness suitable for microscopic examination. He also explained the methods employed in preparing thin sections of minute, isolated bodies, such as sand-grains or foraminifera, illustrating the processes experimentally.

At the conclusion of this address, the President proposed a vote of thanks to Prof. Judd and to Mr. Cole for so kindly receiving the Association, and for taking so much pains to make the visit a success. As many of those present were engaged in teaching, or were otherwise interested in scientific, work, the opportunity of inspecting the Schools was highly appreciated. He remarked that if we are behind the chief Continental States in the amount of money devoted to science, and in the number of establishments so maintained, that afternoon's visit would have convinced the Members of the Association that what England does she does well, and that the Science Schools are an institution of which all connected with them may well be proud.

From the lecture-room the party passed into the Biological laboratory, upon the table of which, for this occasion, were placed a large number of microscopes with sections of rocks and minerals, each with its name attached. From this the visitors passed into the advanced and research laboratories for geology, and from thence down the main stairease to the Entrance Hall. 